\title{
FACTORTAME REVISITED AND THE CONSTITUTION REIMAGINED: THE UK SUPREME COURT TAKES ITS FIRST RIDE ON THE HS2 RAIL-LINE
}

Christopher Sargeant ${ }^{*}$

\section{Introduction}

On 10 January 2012, the Coalition Government formally announced its intention to proceed with the development of a high speed rail-line from London to the north of England, a project known colloquially as HS2. ${ }^{1}$ In its consultation paper entitled 'High Speed Rail: Investing in Britain's Future - Decisions and Next Steps' ('the DNS paper'), the Executive affirmed its basic high speed rail strategy and set out its desired methodology to pursue such a goal, namely through the use of two Parliamentary Bills of a hybrid nature. ${ }^{2}$ The first of these Bills is presently before the House of Commons having been proposed on 25 November 2013, ${ }^{3}$ whilst the second is expected in 2017. ${ }^{4}$ The rail-line itself is scheduled to open in phases from 2026 onwards $^{5}$ and is already expected to cost over $£ 50$ billion, ${ }^{6}$ a figure making it amongst the largest and most expensive infrastructure projects ever attempted in the United Kingdom ('the UK').

Notwithstanding such progress, in April 2012, the lawfulness of this intended methodology was questioned via an application for judicial review made by

\footnotetext{
* Editor-in-Chief, UK Supreme Court Annual Review; PhD Candidate, Fitzwilliam College, University of Cambridge. I am grateful to Emily Charlotte Jameson for her comments on a previous draft.

1 Department for Transport, 'High Speed Rail: Investing in Britain's Future - Decisions and Next Steps' (January 2012) <www.gov.uk/government/uploads/system/uploads/attachment_data/file/3648/hs2-decisions-and-next-steps.pdf > accessed 20 April 2015.

2 Ibid.

3 High Speed Rail (London - West Midlands) HC Bill (2013-14 to 2014-15).

4 House of Commons Library, 'Standard Note 7082 - Railways: HS2 Phase 2 \& beyond' (2015) $<$ www.parliament.uk/business/publications/research/briefing-papers/SN07082/railwayshs2-phase-2-beyond> accessed 20 April 2015, 8.

5 Ibid 2.

6 Ibid 1.

7 House of Lords Economic Affairs Committee, The Economics of High Speed 2 (HL 2014-15), 5.
}

Copyright $\odot$ the Author(s).

This work is licensed under a Creative Commons Attribution-NonCommercial-NoDerivs 3.0 License. 
various groups opposed to the scheme. ${ }^{8}$ Although ultimately successful on a lone technical ground concerning a consultation process used, ${ }^{9}$ the substance of this application was entirely rejected, ${ }^{10}$ a decision which was subsequently upheld by the Court of Appeal. ${ }^{11}$ On 15 and 16 October 2013, the matter was thus considered by the UK Supreme Court ('the Court') in the case of $R$ (Buckinghamshire County Council) $v$ Secretary of State for Transport ('HS2'). ${ }^{12}$ By this time, the grounds of review focused on two main issues: firstly, whether the DNS paper should have been preceded by a strategic environmental assessment as required by art 3 of Directive 2001/42 ('the SEAD'); ${ }^{13}$ and secondly, whether the hybrid Bill procedure envisaged by the DNS paper in any event contained sufficient opportunities for effective public participation in the relevant decision-making processes so as to satisfy art 6(4) of Directive 2011/92 ('the EIAD'). ${ }^{14}$ On 22 January 2014, the Justices unanimously dismissed the appeal on both these grounds, thereby allowing work on the project to continue for now. ${ }^{15}$

Leaving aside the importance of the technical conclusions ultimately reached by the Court on these issues, both of which are considered in detail elsewhere, the primary significance of this decision derives instead from the important and undoubtedly welcome reasoning of the Justices concerning the relationship between the UK legal order and that of the European Union ('the EU'). This is most notable in regards its analysis of the extent of the supremacy enjoyed by the latter over the former. In particular, having famously identified in the seminal case of Factortame (No 2) that 'under the terms of the [European Communities] Act of 1972 it has always been clear that it was the duty of a United Kingdom court, when delivering final judgment, to override any rule of national law found to be in conflict with any directly enforceable rule of Community law, ${ }^{16}$ the decision of the Court in HS2 that where the relevant rule of national law amounts to a

\footnotetext{
${ }^{8} R$ (Buckinghamshire County Council) v Secretary of State for Transport [2013] EWHC 481 (Admin).

9 Ibid [681]-[844] (Ouseley J).

10 Ibid [69]-[680] (Ouseley J).

${ }^{11} R$ (Buckinghamshire County Council) v Secretary of State for Transport [2013] EWCA Civ 920.

${ }^{12} R$ (Buckinghamshire County Council) $v$ Secretary of State for Transport [2014] UKSC 3.

${ }^{13}$ Council Directive 2001/42/EC on the assessment of the effects of certain plans and programmes on the environment [2001] OJ L197/30.

${ }^{14}$ Council Directive 2011/92/EU on the assessment of the effects of certain public and private projects on the environment [2011] OJ L26/1.

15 There is however much opposition to the project, see e.g. Economic Affairs Committee (n 7); see also R (HS2 Action Alliance Ltd) v Secretary of State for Transport [2014] EWCA Civ 1578.

${ }^{16} R v$ Secretary of State for Transport ex parte Factortame Ltd (No 2) [1991] 1 AC 603, 659 (Lord Bridge).
} 
'fundamental principle ${ }^{\text {,17 }}$ such a conflict must instead 'be resolved by our courts as an issue arising under the constitutional law of the United Kingdom ${ }^{\text {'18 }}$ and that there 'may be fundamental principles, whether contained in other constitutional instruments or recognised at common law, of which Parliament when it enacted the European Communities Act 1972 did not either contemplate or authorise the abrogation ${ }^{\prime 19}$ conversely suggests a more nuanced, realistic and altogether more satisfactory analysis of both these specific issues and of the constitutional relationship between the two bodies more generally.

In addition to challenging the classical conception of the doctrine of the supremacy of EU law and reinvigorating the Kompetenz-Kompetenz debate between the Court and the Court of Justice of the EU ('the CJEU') however, ${ }^{20}$ the decision in HS2 also provides a fascinating and similarly welcome glimpse into how the Justices view the UK constitutional order more broadly. Of crucial importance in this regard is that the judicial reasoning on display in the case appears to go far beyond the traditional Diceyan orthodoxy in this field and instead suggests a more complex taxonomy of the current constitutional landscape than is ordinarily understood to exist. ${ }^{21}$ As the UK continues to enjoy a period of extensive constitutional reform at both an internal and external level, ${ }^{22}$ with the role of the Court as (at least) a quasi-federal arbitrator also continuing to grow, ${ }^{23}$ the importance of such remarks must not be understated. Whilst the long-term legacy of the HS2 rail-line itself thus remains to be seen, with further political and legal challenges likely, ${ }^{24}$ its namesake judicial decision will conversely inevitably prove both a pivotal and ultimately desirable authority on the UK constitutional order for many years to come. ${ }^{25}$ Whatever else happens therefore, it can safely be assumed that this first trip by the Court on the HS2

${ }^{17}$ HS2 (n 12) [207] (Lord Neuberger and Lord Mance).

${ }^{18}$ Ibid [79] (Lord Reed).

${ }^{19}$ Ibid [207] (Lord Neuberger and Lord Mance).

${ }^{20}$ See Case C-314/85 Foto-Frost v Hauptzollamt Lübeck-Ost [1987] ECR 4199.

${ }^{21}$ See e.g. A Dicey, Introduction to the Study of the Law of the Constitution (Macmillan 1889).

${ }^{22}$ See e.g. Human Rights Act 1998; Scotland Act 1998; Northern Ireland Act 1998; Government of Wales Act 1998; House of Lords Act 1999; Constitutional Reform Act 2005.

${ }^{23}$ See e.g. Local Government Byelaws (Wales) Bill 2012 - Reference by the AG for England and Wales [2012] UKSC 53; Agricultural Sector (Wales) Bill - Reference by the AG for England and Wales [2014] UKSC 43; Recovery of Medical Costs for Asbestos Diseases (Wales) Bill - Reference by the CG for Wales [2015] UKSC 3.

${ }^{24}$ See e.g. Economic Affairs Committee (n 7).

25 The decision must surely be included alongside decisions such as $A v$ Secretary of State for the Home Department [2004] UKHL 56; Pepper v Hart [1993] AC 593; Factortame (No 2) (n 16); Bank Mellat v HM Treasury (No 1) [2013] UKSC 38 as amongst the most important in UK law. 
rail-line will ultimately not be its last.

\section{HS2 - Background}

\subsection{Factual Overview}

First seen in 2003 as part of the Channel Tunnel rail-link with France ('HS1'), the possibility of a second high speed rail-line in the UK was initially mooted by the (then) Labour Government in 2009 to address concerns over the current West Coast main-line which will reach its full operational capacity by 2025 . $^{26}$ Officially defined as any new rail-line with a top speed of over $250 \mathrm{kph}$ or any existing line with a top speed of over $200 \mathrm{kph},{ }^{27}$ this discussion eventually led the Government to pledge to build just such a line from London to Birmingham and then onwards to Manchester and Leeds ('HS2'). ${ }^{28}$ This commitment thereafter survived the change in government later that year and was explicitly agreed upon in the Conservative-Liberal Democrat Coalition agreement in May 2010. ${ }^{29}$

In order to ensure that this new HS2 project was subsequently pursued as effectively as possible, on 10 January 2012, the (then) Secretary of State for Transport, Justine Greening MP, set out the future approach of the (new) Government to this goal in its DNS paper. ${ }^{30}$ This firstly set out the latest version of the plan, namely for a single rail-line from London to Birmingham to be completed by 2026 and then for a spur extension to run to both Manchester and Leeds by $2033 .{ }^{31}$ It secondly described the consultation processes needed for the project and also the methodology by which the requisite legal authority was to be sought, namely via two Parliamentary Bills of a hybrid nature. ${ }^{32}$ The first such Bill is now before the House of Commons having been proposed on 25 November $2013,{ }^{33}$ whilst the second is expected in 2017 with construction scheduled for

\footnotetext{
${ }^{26}$ Standard Note 7082 (n 4), 2-3.

${ }^{27}$ Council Directive 1996/48/EC on the interoperability of the trans-European high-speed rail system [1996] OJ L235/6, Annex I, [1b].

${ }^{28}$ Department for Transport, High Speed Rail (March 2010) <www.gov.uk/government/uploads/system/uploads/attachment_data/file/228887/7827.pdf.> accessed 20 April 2015.

${ }^{29}$ HM Government, The Coalition: our programme for government $(2010)<w w w . g o v . u k / g o v e r n-$ ment/uploads/system/uploads/attachment_data/file/78977/coalition_programme_for_government.pdf > accessed 20 April 2015, 31.

${ }^{30}$ DNS Paper (n 1$)$.

${ }^{31}$ Ibid 12. Further extensions of the line between Manchester and Leeds ('HS3') and also into Scotland have also been mooted, but neither is not presently formal Government policy.

${ }^{32}$ Ibid 37.

${ }^{33}$ High Speed Rail (London - West Midlands) HC Bill (n 3).
} 
shortly thereafter. ${ }^{34}$

\subsection{The Case Before the Lower Courts}

\subsubsection{The High Court}

Given the significant potential impact and expense of the HS2 scheme as set out in the DNS paper, its proposals were unsurprisingly immediately challenged by way of a wide-ranging application for judicial review made by a collection of anti-HS2 groups. ${ }^{35}$ In the High Court, Ouseley J dismissed the substance of this challenge, albeit he ultimately allowed the action based on a lone procedural ground concerning a consultation process used. ${ }^{36}$ In particular, he found that the Secretary of State had not made 'sufficient information available to consultees at the first stage for the consultation process to be fair ${ }^{37}$ and also that she had failed to properly consider the consultation responses of a 'key stakeholder.' ${ }^{38}$ In his view, these failures made the process 'so unfair as to be unlawful'. ${ }^{39}$

\subsubsection{The Court of Appeal}

The majority of the rejected substance of the case was thereafter appealed to the Court of Appeal. ${ }^{40}$ Heard by Dyson, Richards and Sullivan LJJ, the primary issue was now whether the DNS paper amounted to 'a plan or programme' which 'set the framework for future development consent' for the purposes of arts 2 and 3 of the SEAD. ${ }^{41}$ If it did, it should have been preceded by a strategic environmental assessment of the project, a review which did not exist on the facts. ${ }^{42}$ In addition, it was also argued that the use of two Parliamentary Bills of a hybrid nature to pursue the relevant legal authorisations needed for the project did not comply with art 6 of the EAID as these offered insufficient opportunities for effective public participation in the key decision-making processes. By a majority, albeit with Sullivan LJ dissenting on the first ground, the case was again dismissed. On

\footnotetext{
${ }^{34}$ Standard Note 7082 (n 4) 6-7.

${ }^{35}$ HS2 (HC) (n 8).

${ }^{36}$ See in particular ibid [681]-[844] (Ouseley J). This aspect of the decision appears to have been accepted by the Government as it was not subsequently appealed.

${ }^{37}$ Ibid [761] (Ouseley J).

${ }^{38}$ Ibid [841] (Ouseley J).

${ }^{39}$ Ibid [843] (Ouseley J).

${ }^{40}$ HS2 (CA) (n 11).

${ }^{41}$ Council Directive 2001/42/EC (n 13) art 3(2)(a).

${ }^{42}$ Ibid art 3(1).
} 
the first ground, the Court held that no strategic environmental assessment was required as the DNS paper did not amount to a 'plan or programme' in so far as it had 'no legal influence on Parliament [which] ... is not obliged to comply with it or even to have regard to it in reaching its decision on whether to give consent to the development. ${ }^{43}$ On the second ground, the Court endorsed the finding of Ouseley J that it was inconceivable that the UK Parliament would be unable to meet the objectives of the Directive. It has given no indication at all that it has set its face against compliance. ${ }^{44}$

\section{HS2 before the Supreme Court - 'Factortame Revisited'}

\subsection{Introduction}

As a result of the failure of the challenge to the DNS paper and its contents before the lower courts, the case was finally appealed to the Supreme Court. ${ }^{45}$ Heard between 15 and 16 October 2013, the grounds of review were essentially the same as those argued before the Court of Appeal, namely that the DNS paper should have been preceded by a strategic environmental assessment for the purposes of the SEAD and that the envisaged hybrid Bill procedure did not meet the requirements of the EAID. On 22 January 2014, the appeal was unanimously dismissed by the Court on both grounds. On the first ground, Lord Carnwath (writing for the Court) held that the DNS paper was:

a very elaborate description of the HS2 project, including the thinking behind it and the government's reasons for rejecting alternatives. In one sense, it might be seen as helping to set the framework for the subsequent debate, and it is intended to influence its result. But [crucially] it does not in any way constrain the decision-making process of the authority responsible, which in this case is Parliament. ${ }^{46}$

On the latter ground, Lord Reed (similarly writing for the Court) again held that the hybrid Bill procedure did comply with the EAID in so far as its relevant

\footnotetext{
${ }^{43}$ HS2 (CA) (n 11) [56] (Dyson and Richards LJJ).

${ }^{44}$ Ibid [82] (Lord Dyson and Richards LJJ); see also HS2 (HC) (n 8) [271] (Ouseley J).

${ }^{45}$ HS2 (UKSC) (n 12).

${ }^{46}$ Ibid [38] (Lord Carnwath); cf Walton v Scottish Ministers [2012] UKSC 44.
} 
processes allowed for both Houses of Parliament to consider any information relevant to the issue being debated ${ }^{47}$ and that whilst the relevant Parliamentary votes would be both time-limited and whipped, with the basis commitment to a high speed rail-line itself beyond challenge, there was nothing in the case law of the Court of Justice [of the European Union or of the domestic Courts] to suggest that the influence of parliamentary parties, or of Government, over voting in national legislatures ${ }^{48}$ was incompatible with ensuring the effective public oversight of such projects for these purposes.

Notwithstanding the importance of these technical conclusions however, both of which are analysed in detail elsewhere, the true significance of this decision derives instead from the consideration by the Court of a preliminary constitutional issue as part of the second ground of appeal which, albeit ultimately strictly obiter on the specific facts at issue, ${ }^{49}$ was nonetheless raised by the Court and forms a key part of its judgment. In particular, whilst art 6 of the EAID requires (at least in principle) that the Court can determine whether the UK Parliament is 'able properly to examine and debate the environmental effects of the [HS2] project'; ${ }^{30}$ art 9 of the Bill of Rights 1688 ('the Bill of Rights') conversely expressly precludes 'the impeaching or questioning in any court of debates or proceedings in Parliament. ${ }^{51}$ A requirement in EU law that the Court can examine the compatibility of Parliamentary proceedings with the terms of a directive thus potentially directly conflicted with a requirement in UK domestic law not to perform such an action. How was such a conflict to be resolved by the Court?

\subsection{The Relationship Between the UK and EU Legal Orders}

\subsubsection{The Basic Principle: The Decision in Factortame (No 2)}

As every law student knows, a conflict between the UK and EU legal orders is ordinarily resolved by reference to the doctrine of the supremacy of EU law as explained by the House of Lords in its seminal decision in Factortame (No 2). ${ }^{52}$ In this case, Lord Bridge held that where a conflict arose between a rule of national law and a directly effective rule of EU law, the operation of the former law is to

\footnotetext{
${ }^{47}$ Ibid [99] (Lord Reed).

${ }^{48}$ Ibid [101] (Lord Reed).

${ }^{49}$ Ibid [99] (Lord Reed).

${ }^{50}$ Case C-43/10 Nomarchiaki Aftodioikisi Aitoloakarnanias [2013] Env LR 21, [136]-[37] (AG Kokott).

${ }^{51}$ HS2 (UKSC) (n 12) [203] (Lord Neuberger and Lord Mance).

${ }^{52}$ Factortame (No 2) (n 16).
} 
be considered suspended in favour of the latter so as to protect the effectiveness of the EU legal regime. ${ }^{53}$ This result was not however the subject of detailed analysis but was instead justified solely by reference to a cryptic statement by his Lordship that it has 'always been clear that it was the duty of a United Kingdom court when delivering final judgment, to override any rule of national law found to be in conflict with any directly enforceable rule of Community law. ${ }^{54}$ This was true since this doctrine was 'well established in the jurisprudence of the European Court of Justice long before the United Kingdom joined the Community ${ }^{55}$ and was thus beyond question in this case.

\subsubsection{The Problem of Conflicting Constitutional Principles: The Decision in $\mathrm{HS2}$}

In HS2 by contrast, the Court did not conceptualise the case as a matter concerning the effectiveness of EU law as it had done in Factortame (No 2), but rather approached it as a decision involving a clash between two conflicting constitutional norms. Art 9 of the Bill of Rights was thus understood not as a mere 'rule' of national law, as the House of Lords had previously described the provisions of Part 2 of the Merchant Shipping Act 1988, but instead as one of the 'long-established constitutional principles governing the relationship between Parliament and the courts', ${ }^{56}$ 'one of the pillars of constitutional settlement which established the rule of law in England in the 17th century ${ }^{57}$ and as a rule 'of the highest constitutional importance [which] should not be narrowly construed' ${ }^{58}$ Unsurprisingly, a conflict between such a norm and the doctrine of the supremacy of EU law was inevitably considered far more difficult to resolve than clashes in previous cases of this kind. More controversially, the Court did not simply resort to the classical solution to the issue as per Factortame (No 2), but rather sought to present the relationship between the two legal orders in a more nuanced and flexible manner than has previously been seen. As Lord Neuberger and Lord Mance thus noted:

\footnotetext{
${ }^{53}$ Ibid 659 (Lord Bridge); see also Case C-213/89 R v Secretary of State for Transport ex parte Factortame Ltd [1990] ECR I-2433, [21].

${ }^{54}$ Ibid.

${ }^{55}$ Ibid 658-9 (Lord Bridge).

${ }^{56}$ HS2 (UKSC) (n 12) [78] (Lord Reed).

${ }^{57}$ Ibid [203] (Lord Neuberger and Lord Mance; see also $R v$ Chaytor [2010] UKSC 52, [110] (Lord Rodger).

${ }^{58}$ HS2 (UKSC) (n 12) [203] (Lord Neuberger and Lord Mance) citing Pepper v Hart [1993] AC 593, 638 (Lord Browne-Wilkinson).
} 
It is, putting the point at its lowest, certainly arguable (and it is for United Kingdom law and courts to determine) that there may be fundamental principles, whether contained in other constitutional instruments or recognised at common law, of which Parliament when it enacted the European Communities Act 1972 did not either contemplate or authorise the abrogation. ${ }^{59}$

This statement underpins two key but also welcome ideas regarding the ambit of the doctrine of the supremacy of EU law. The first is that there 'may be fundamental principles, whether contained in other constitutional instruments or recognised at common law, of which Parliament when it enacted the European Communities Act 1972 did not either contemplate or authorise the abrogation' ${ }^{60}$ Whilst this issue is not determined conclusively, as the Court noted, 'we would wish to hear full argument upon it before expressing any concluded view, ${ }^{61}$ this clearly challenges the absolutist approach to this doctrine as was seemingly set out in Factortame (No 2). Indeed, it now appears that whilst some rules of national law must still be considered subservient to any conflicting rule of directly effective EU law, others are now considered to be superior and thus need not. To mark the contours of this new framework, the Court, via Lord Neuberger and Lord Mance, thereafter went on to distinguish between 'ordinary' and 'constitutional' legislation, ${ }^{62}$ with the latter category enjoying special protection from the effect of laws in the former by virtue of such status. Despite stopping short of directly endorsing the past dicta of Laws LJ in the case of Thoburn which had previously drawn just such a distinction, ${ }^{63}$ they also noted that this decision offers 'important insights' and a 'penetrating discussion' of the relevant issues in this field. ${ }^{64}$ Accordingly, although this issue will inevitably be subject to further litigation and judicial analysis, Lord Neuberger and Lord Mance were finally prepared to venture a preliminary list of current constitutional principles. In their view:

They include Magna Carta, the Petition of Right 1628, the Bill of Rights and (in Scotland) the Claim of Rights Act 1689, the Act of Settlement 1701 and the Act of Union 1707. The European Communities

\footnotetext{
${ }^{59}$ Ibid [207] (Lord Neuberger and Lord Mance).

${ }^{60}$ Ibid.

${ }^{61}$ Ibid [208] (Lord Neuberger and Lord Mance).

${ }^{62}$ Ibid [208] (Lord Neuberger and Lord Mance).

${ }^{63}$ Thoburn v Sunderland City Council [2002] EWHC 195 (Admin) [58]-[70] (Laws LJ).

${ }^{64}$ HS2 (UKSC) (n 12) [208] (Lord Neuberger and Lord Mance).
} 
Act 1972, the Human Rights Act 1998 and the Constitutional Reform Act 2005 may now be added to this list. The common law itself also recognises certain principles as fundamental to the rule of law. ${ }^{65}$

The second critical idea raised is that the precise effect of a conflict between such a 'fundamental principle ${ }^{\prime 66}$ and a directly effective rule of EU law is a matter to be 'resolved by our [UK] courts as an issue arising under the constitutional law of the United Kingdom ${ }^{67}$ and not simply by reference to the absolutist approach of the CJEU which had been essentially endorsed by the House of Lords in Factortame (No 2). ${ }^{68}$ This argument touches upon a long-standing debate between the CJEU and senior appellate courts within its member states concerning who has the power to determine the limits and boundaries of the EU legal order. ${ }^{69}$ Whilst in Factortame (No 2), Lord Bridge took a relatively docile approach to this issue, in essence deferring to the CJEU, ${ }^{70}$ the Court in HS2 was conversely far clearer that future disputes of this kind must now be determined by reference to a domestic law perspective. As Lord Reed thus notes, the case cannot 'be resolved simply by applying the doctrine developed by the Court of Justice of the supremacy of EU law, since the application of that doctrine in our law itself depends upon the [European Communities Act 1972]. ${ }^{, 71}$

Taken together, these two ideas indicate that the decision in Factortame (No 2) is no longer to be seen as the only or even the primary guide to any analysis of the legal relationship between the UK and EU legal orders. By itself this is unsurprising: as noted above, whilst that decision is seminal in regards its conclusions, it contains minimal explanation of how such conclusions were reached. Nonetheless, the specific approach set out by the Court in HS2 must also be seen as encouraging in its own right. This argument is advanced on two grounds. Firstly, in recognising the European Communities Act 1972 ('the 1972 Act') as a constitutional statute, the decision provides a sound conceptual basis for the operation of the doctrine of the supremacy of EU law within the UK legal

\footnotetext{
${ }^{65}$ Ibid [207] (Lord Neuberger and Lord Mance).

${ }^{66}$ Ibid.

${ }^{67}$ Ibid [79] (Lord Reed).

${ }^{68}$ See e.g. Case 26/62 Van Gend en Loos v Netherlands [1963] ECR 1; Case 6/64 Flaminio Costa v ENEL [1964] ECR 585; Case 11/70 International Handelsgesellschaft mbH v Einfuhr [1970] ECR 1125; Case 106/77 Simmental II [1978] ECR 629.

${ }^{69}$ See e.g. V Trstenjak, 'National Sovereignty and the Principle of Primacy in EU Law and Their Importance for the Member States' (2013) 4(2) Beijing Law Review 71.

${ }^{70}$ Factortame (No 2) (n 16) 658-59 (Lord Bridge).

${ }^{71}$ HS2 (UKSC) (n 12) [79] (Lord Reed).
} 
order by explaining that, by virtue of such superior status, the doctrine, via the 1972 Act, ensures the repeal (or at least the suspension) of any 'ordinary' (inferior) domestic rule which is impliedly inconsistent with a directly effective EU law. Without such standing, it is hard to see how and why laws passed subsequent to the 1972 Act which are inconsistent with its terms do not impliedly repeal its provisions, a result which can be neither accurate, not least in the light of Factortame (No 2) itself, nor desirable given the need for at least some degree of wider constitutional stability in the UK legal order.

At the same time, the qualified nature of the decision in HS2 conversely leaves open the entirely sensible possibility that Parliament may explicitly legislate inconsistently with its duties under EU law and also that there may be other constitutional laws of an equal or even superior status to the 1972 Act which cannot therefore be impliedly repealed in this way. This latter qualification is likely the most crucial part of the decision in HS2 in so far as it situates the doctrine of the supremacy of EU law squarely within the broad contours of the UK legal order itself rather than leaving it on the outside and free from such controls as was previously the case. ${ }^{72}$ As a result, it now appears that an EU law may be refused entry into the UK legal order on the basis that it is inconsistent with another UK legal principle considered more fundamental than the 1972 Act. $^{73}$ Whilst the boundaries of this new framework are again yet to be conclusively determined, it is also clear that such determinations must occur from a domestic law perspective. ${ }^{74}$ This is again clearly sensible. If, as Lord Bridge rightly notes in Factortame (No 2), the UK Parliament has limited its sovereignty (at least de-facto) on an 'entirely voluntary' basis, ${ }^{75}$ there must inevitably still be a role for the UK Courts, even without a formal constitution in support, ${ }^{76}$ to decide how far this limitation extends and what the effects of an EU law outside of such limits should be. Finally, this purposefulness by the Court also corresponds with similar displays of assertiveness shown by fellow apex courts in the EU, most notably in

\footnotetext{
72 This has previously been hinted at in other contexts: see e.g. Macarthys $v$ Smith [1979] 3 All ER 325, 329 (Lord Denning).

73 See e.g. HS2 (UKSC) (n 12) [78]-[79], [96]-[97] (Lord Reed), [198]-[211] (Lord Neuberger and Lord Mance).

${ }^{74}$ Ibid [79] (Lord Reed).

${ }^{75}$ Factortame (No 2) (n 16) 659 (Lord Bridge).

${ }^{76}$ See Lord Neuberger, 'The British and Europe' (Cambridge Freshfields Annual Law Lecture 2014, 12 February 2014), [34] <https://www.supremecourt.uk/docs/speech-140212.pdf> accessed 20 April 2015.
} 
Germany $^{77}$ and the Czech Republic ${ }^{78}$ and also with the more recent approach of the Court itself to the European Court of Human Rights. ${ }^{79}$ These challenges have ultimately led to increased levels of judicial dialogue between those Courts and thus also to more informed and likely superior case law as a result. ${ }^{80}$

\section{The Long Term Consequences of HS2 - 'The Constitution Re-imagined'}

In addition to repositioning the doctrine of the supremacy of EU law within the contours of the UK legal order and reinvigorating the jurisdictional debate between the Court and the CJEU, ${ }^{81}$ the decision in HS2 also provides a detailed and similarly welcome insight into how the Justices of the Court view the UK constitutional order more broadly. Crucially, their reasoning in this regard appears to transcend the classic Diceyan orthodoxy in this field and instead suggests both a more nuanced, complex and also welcome view of our constitutional landscape than is ordinarily understood to exist. ${ }^{82}$ In this regard, the recent analysis of this issue by Dr Mark Elliott in the European Constitutional Law Review is considered particularly insightful and thus forms the substantial backdrop to the comments which follow here. ${ }^{83}$

\subsection{Parliamentary Sovereignty and the 'Flat' Constitution}

To appreciate the broader value of the decision in HS2, it is first necessary to consider the classical view of the UK constitutional order, with the doctrine of

\footnotetext{
${ }^{77}$ See e.g. Internationale Handelsgesellschaft (n 68); Solange I [1974] 2 CMLR 540; Solange II [1987] 3 CMLR 225; Brunner v European Union Treaty [1994] 1 CMLR 57; Honeywell Bremsbelag GmbH (2010) 2 BvR 2661/06; Lissabon-Urteil (2009) 2 BvE 2/2008; Gauweiler (2014) 2 BvR 2728/13.

${ }^{78}$ Case 5/12 Slovak Pensions (Czech Constitutional Court, 31 January 2012).

${ }^{79}$ See e.g. $R v$ Horncastle [2009] UKSC 14; $R$ (Animal Defenders International) $v$ Secretary of State for Culture, Media and Sport [2008] UKHL 15; $R v$ Spear [2002] UKHL 31.

${ }^{80}$ See e.g. Lady Justice Arden, 'Peaceful or Problematic? The Relationship between National Supreme Courts and Supranational Courts in Europe' (2010) 29 Yearbook of European Law 3, 13; Lord Kerr, 'The UK Supreme Court: The Modest Underworker of Strasbourg?' (Clifford Chance Lecture, 25 January 2012), 7 <https://www.supremecourt.uk/docs/speech_120125.pdf> accessed 20 April 2015; see also Al-Khawaja v United Kingdom (2012) 54 EHRR 23; Cooper v United Kingdom (2004) 39 EHRR 8; Animal Defenders International v United Kingdom (2013) 57 EHRR 21.

${ }^{81}$ See e.g. Factortame (No 2) (n 16); Foto-Frost (n 20).

${ }^{82}$ See e.g. Dicey (n 21).

${ }^{83}$ M Elliott, 'Constitutional Legislation, European Union Law and the Nature of the United Kingdom's Contemporary Constitution’ (2014) 10(3) European Constitutional Law Review 379.
} 
parliamentary sovereignty as its 'bedrock' ${ }^{\prime 24}$ and as the 'dominant characteristic of our political institutions. ${ }^{85}$ At the apex of this framework is the idea that Parliament has 'the right to make or unmake any law whatever [and that] ... no person or body [has] ... a [legal] right to override or set aside the legislation of Parliament.' 86 Also contained within this model is the so-called "flat" constitution, ${ }^{87}$ namely that there is no legal "hierarchy of legislation ... [such that] every Act is the legal equal of every other such Act. ${ }^{88}$ As Dicey thus notes, 'neither the Act of Union with Scotland ... nor the Dentists Act 1878 ... has more claim than the other to be considered a supreme law. ${ }^{, 89}$ In a more modern example, the 1972 Act is thus no more legally supreme than the Salmon Act 1986 or the Protection of Badgers Act 1992.

\section{2 'Constitutional' Legislation}

Even taken at its highest, the decision in HS2 does not fundamentally doubt the constitutional order set out above, but rather seems to re-frame its dimensions and re-evaluate its inner workings. Whilst it will clearly be far from the last word on such matters, it nonetheless represents amongst the most crucial observations on their scope in recent times. This is most obvious in regards the approval, albeit not outright endorsement, by the Court of the dicta of Laws LJ in Thoburn that the UK legal order is not as 'flat' as has previously been suggested and can instead be split into two subsets of 'ordinary' and 'constitutional' legislation, each with differing consequences attached to them. ${ }^{90}$ Notwithstanding that such a view is both pre-existing and also eminently sensible in light of the obvious factual divergences in the relative importance of different pieces of law, this support is key in so far as it signals judicial approval at the highest level for the idea that not all pieces of legislation are created equal, an idea traditionally considered heretical from a legal perspective. As Elliott therefore rightly explains in this regard, the decision in HS2 'confers upon the idea of [constitutional statutes] an authoritative imprimatur that is has hitherto lacked. ${ }^{91}$ Similarly, in so far as Lord Neuberger

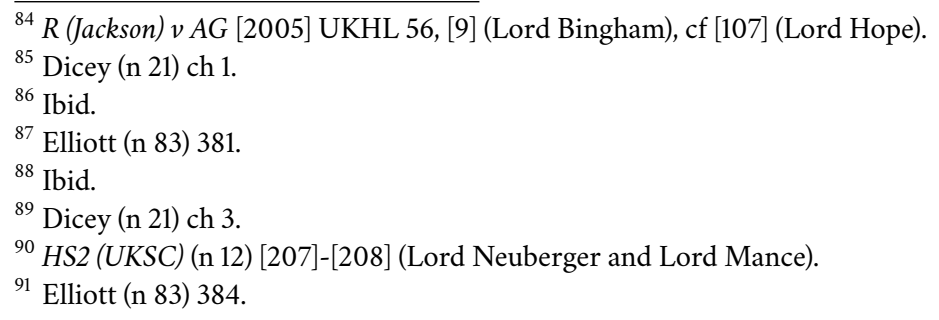


and Lord Mance endorse a general list of instruments enjoying such status, ${ }^{92}$ especially one so closely aligned with that in Thoburn itself, ${ }^{93}$ this ensures that much of the detailed scholarship already in existence on this topic continues to be of relevance and that the field can accordingly be rapidly developed. Whilst Elliott is accordingly again right to note that if the 'notion of constitution measures ... is to develop into a meaningful one, then a good deal of definitional work remains to be done, ${ }^{, 94}$ the scale of this task should not be overstated given the key work already complete. ${ }^{95}$ On any reading, the idea of the constitutional statute is thus now entrenched in the UK legal order and is likely to form a key part of our constitutional lexicon for many years to come.

\section{3 'Constitutional' Legislation of Varying Fundamentality}

Also worthy of note are the wider constitutional consequences of the support by the Court of the multi-level legal framework seen above. Most importantly, the establishment of a hierarchy based on 'ordinary' and 'constitutional' law suggests a corresponding need for a new way to determine the relative importance of the laws within each category vis-à-vis each other. Although the Court in HS2 is careful not to formally resolve this issue, the words of Lord Neuberger and Lord Mance that there 'may be fundamental principles, whether contained in other constitutional instruments or recognised at common law, of which Parliament when it enacted the European Communities Act 1972 did not either contemplate or authorise the abrogation ${ }^{\prime 96}$ seem to suggest that in the absence of a provision providing for the explicit repeal of a relevant earlier 'constitutional' law, such an assessment will likely occur based on the varying fundamentality of the two conflicting laws at issue. As Elliott thus notes:

[The] more appealing ... possibility ... [is that this] represents a development of the approach set out in Thoburn ... [and] signals a shift away from a bright-line distinction between ordinary and constitutional legislation, and instead embraces a more nuanced

\footnotetext{
${ }^{92}$ HS2 (UKSC) (n 12) [207] (Lord Neuberger and Lord Mance).

${ }^{93}$ Thoburn (n 63) [62] (Laws LJ).

${ }^{94}$ Elliott (n 83) 386.

${ }^{95}$ See e.g. D Feldman, 'The Nature and Significance of “Constitutional” Legislation' (2013) 129 LQR 343.

${ }^{96}$ HS2 (UKSC) (n 12) [207] (Lord Neuberger and Lord Mance).
} 
approach that is capable of accommodating varying degrees of constitutional fundamentality. ${ }^{97}$

If followed through in subsequent cases, this will likely prove a particularly radical step. Whilst such norms will certainly not acquire constitutional status of the kind understood in states with a written constitution or bill of rights such as the US or Germany, ${ }^{98}$ this aspect of the decision in HS2 effectively subjects such rules to a new, widely drawn, interpretative obligation akin to that which already protects fundamental rights via the principle of legality, with more fundamental laws considered ever more difficult to dislodge. ${ }^{99}$ As such, although 'Parliament can override legislation that reflects fundamental constitutional principles, it must speak clearly when it wishes to do so: and ... the more fundamental the principle in question, the more clearly Parliament must signal its intention.' ${ }^{\text {,00 }}$ To paraphrase Lord Hoffmann in ex parte Simms therefore, it is now the case that:

[Constitutional laws] cannot be overridden by general or ambiguous words. This is because there is too great a risk that the full implications of their unqualified meaning may have passed unnoticed in the democratic process. In the absence of express language or necessary implication to the contrary, the courts therefore presume that even the most general words were intended to be subject to the basic [constitutional principles of this jurisdiction]. In this way the courts of the United Kingdom, though acknowledging the sovereignty of Parliament, apply principles of constitutionality little different from those which exist in countries where the power of the legislature is expressly limited by a constitutional document. ${ }^{101}$

Notwithstanding that this change marks an expansion of the principle of legality far beyond anything this country has previously seen, the benefits of such a development are obvious. Whilst it remains, at least in principle, open to legislators to expressly amend even our most critical constitutional provisions, a rule of interpretation which prevents them from doing so without a clear expression of their will must, on any reading, be eminently desirable. This is

\footnotetext{
${ }^{97}$ Elliott (n 83) 388-89.

${ }^{98}$ HS2 (UKSC) (n 12) [207] (Lord Neuberger and Lord Mance).

${ }^{99}$ See e.g. $R v$ Secretary of State for the Home Department ex parte Pierson [1998] AC 539, 573-75 (Lord Browne-Wilkinson).

${ }^{100}$ Elliott (n 83) 389.

${ }^{101} R v$ Secretary of State for the Home Department; ex parte Simms [2000] 2 AC 115, 131 (Lord Hoffmann).
} 
particularly so given the level of additional protection that an approach of this kind garners for such provisions simply via the imposition of a requirement that legislators confront their choices on such matters head on. Nor is this an issue which is simply of a cerebral nature; indeed changes of this kind may potentially have huge practical effects on both UK residents and also those subject to its protection around the world. On any reading, this is thus again a highly positive development for the UK legal order and should be understood in this light.

\subsection{A Role for the Common Law and for Constitutional Principles}

Any discussion of the impact of the decision in HS2 must finally have regard to the common law. In framing such comments, it must first however be realised that this is an area which is itself enjoying a significant resurgence in importance. In four further recent decisions of the Court, namely Osborn, ${ }^{102}$ Kennedy, ${ }^{103} A^{104}$ and Moohan, ${ }^{105}$ the Justices have clearly chosen to emphasise the key role played by common law rights and have also reminded counsel not to pay too 'little attention to domestic administrative law ${ }^{106}$ by focusing too greatly on the statutory rights found within the Human Rights Act 1998 ('the HRA'). As Lord Reed notes in Osborn, the HRA does not 'supersede the protection of human rights under the common law [...] Human rights continue to be protected by our domestic law, interpreted and developed in accordance with the Act when appropriate. ${ }^{, 107}$ Similarly for Lord Toulson, " $t$ the development of the common law did not come to an end on the passing of the Human Rights Act. It is in vigorous health and flourishing in many parts of the world which share a common legal tradition. ${ }^{\prime 108}$ As he adds elsewhere, it was not the purpose of the Human Rights Act that the common law should become an ossuary.'109

Although in one sense, these statements simply remind us of the perilous position currently enjoyed by the HRA; ${ }^{110}$ their future impact is likely to be

\footnotetext{
$\overline{{ }^{102} \text { Osborn v Parole Board [2013] UKSC } 61 .}$

${ }^{103}$ Kennedy $v$ Charity Commission [2014] UKSC 20.

${ }^{104} A v$ British Broadcasting Corporation (Scotland) [2014] UKSC 25.

${ }^{105}$ Moohan v Lord Advocate [2014] UKSC 67.

${ }^{106}$ Osborn (n 102) [54] (Lord Reed).

${ }^{107} \mathrm{Ibid}[57]$ (Lord Reed).

${ }^{108} R$ (Guardian News and Media Ltd) v City of Westminster Magistrates' Court [2012] EWCA Civ 420, [88] (Toulson LJ).

${ }^{109}$ Kennedy (n 103) [133] (Lord Toulson).

${ }^{110}$ See Conservative Party, Protecting Human Rights in the UK: The Conservatives' Proposals for Chang-
} 
significantly broader. It is unsurprising, for example, that Lady Hale has recently referred to such cases as having led to 'a renaissance of UK constitutional rights' and also a period of 'UK Constitutionalism on the March', ${ }^{\text {'11 }}$ nor that the Court in HS2 was itself quick to note that the 'common law itself also recognises certain principles as fundamental to the rule of law' ${ }^{112}$ when discussing which laws may enjoy constitutional status. As Lady Hale also rightly argues, this indicates an ever 'growing awareness of the extent to which the UK's constitutional principles should be at the forefront of the court's analysis ${ }^{\prime 113}$ and reflects the value of what Elliott calls the new and 'particularly rich vision of the UK's unwritten constitutional order ${ }^{114}$ that has been developed in recent cases such as HS2.

Crucially however, the expansion of the taxonomy of the UK constitutional order engendered by such cases goes far beyond simply broadening the number of its available sources. In addition, it also touches upon a further key idea expressed in HS2 itself, namely that it is the importance of the 'principle' which underpins a law, rather than its technical legal basis, which determines whether it is to be treated as being of an 'ordinary' or 'constitutional' nature. That this view is correct can be seen by re-examining the previously cited words of Lord Reed in HS2 itself, when he notes that:

The argument presented ... if well founded, impinges upon longestablished constitutional principles governing the relationship between Parliament and the courts, as reflected for example in article 9 of the Bill of Rights 1689 ... Nevertheless, it follows that the [claimants'] contentions potentially raise a question as to the extent, if any, to which these principles may have been implicitly qualified or abrogated by the European Communities Act 1972. ${ }^{115}$

As in regards other aspects of the decision in HS2, it is vital that the importance of such remarks is not understated. Whilst, as noted previously, such norms will not now suddenly enjoy a status akin to provisions in a formal constitution or bill of rights, this nonetheless clearly represents a substantial intrusion into the legislative freedom of Parliament in so far as it seems to confer

\footnotetext{
ing Britain's Human Rights Laws (2015) <https://www.conservatives.com/ /media/files/downloadable\%20Files/human_rights.pdf> accessed 20 April 2015.

${ }^{111}$ Lady Hale, 'UK Constitutionalism on the March?' (2014) 19 Judicial Review 201, 201, 208.

${ }^{112}$ HS2 (UKSC) (n 12) [207] (Lord Neuberger and Lord Mance).

${ }^{113}$ Hale (n 111) 208.

${ }^{114}$ Elliott (n 83) 390.

${ }^{115}$ HS2 (UKSC) (n 12) [78] (Lord Reed) [Emphasis added].
} 
free-standing protection upon certain ideas underpinning the very nature of the State itself and its most important operational powers absent express legal words concerning their amendment. Such a possibility suggests a constitutional richness which is again clearly ill at ease with the 'flat' Diceyan orthodoxy set out above and at least de-facto 'knocks some of the hard edges off the notion of absolute legislative supremacy. ${ }^{116}$ Whilst this development will inevitably again be the subject of significant further litigation in the future, in so far as it prevents fundamental constitutional reform being carried out absent an express clarification to such effect, this must once again also be seen as a positive development for both the State and its citizens and as a desirable legal change by the Court.

\section{Conclusion}

In a paper from 2010 by the House of Commons Library, it was estimated that around $21 \%$ of all UK laws and $50 \%$ of such laws with a significant economic impact originated from within the EU. ${ }^{117}$ As a result, an effective relationship between the UK and EU legal orders is thus an issue of the highest constitutional importance. In this light, the decision of the Court in HS2 to depart from the absolutist approach to the doctrine of the supremacy of EU law set out some 25 years previously by the House of Lords in Factortame (No 2) might therefore seem an unnecessary complication of an otherwise simple and easy to understand solution to a difficult legal problem.

Despite this, by affirming the status of the 1972 Act as a constitutional statute and also situating the doctrine of the supremacy of EU law squarely within the broad contours of the UK legal order itself, this approach, in many ways, allows the UK to have the best of both worlds. One the one hand, it firstly confers a proper conceptual basis for the operation of the doctrine within the UK legal order, a result not delivered in Factortame (No 2) itself. By doing so however, it simultaneously also ensures that the doctrine's scope and ambit are now (at least in principle) laid open to control by the distinguishing characteristics of the constitutional framework of this country. Whilst in the vast majority of cases, this will admittedly make no factual difference at all to the particular parties

\footnotetext{
${ }^{116}$ Elliott (n 83) 392.

${ }^{117}$ House of Commons Library, 'How Much Legislation Comes from Europe? (2010) Research Paper 10/62, 1 <http://www.parliament.uk/briefing-papers/RP10-62.pdf> accessed 20 April 2015.
} 
concerned, in a structural sense, it represents a significant re-balancing of the relationship between the EU and the UK legal orders and recognises that the 1972 Act did not write the EU institutions 'a blank cheque', ${ }^{118}$ but rather involved the voluntary acceptance by the UK of a limited restriction on its sovereignty for as long as the UK sees fit. Understood in this light, it stands to reason that this transfer must always remain within the ultimate control of the UK legal order and thus must also be 'subject to general rules of statutory interpretation such as the need for express authority for violations of fundamental rights or of fundamental constitutional principles, and so subject to implied limitation. ${ }^{119}$ This ensures not only that the peculiarities of the UK legal order continue to be respected, but also that the effectiveness of EU legal order is maintained as far as possible.

Conversely however, from a strictly domestic perspective, the decision of the Court in HS2 more broadly represent one of the most expansive examples of judicial reasoning seen in modern times. When taken to its logical conclusions, it is now clear that the constitutional orthodoxy, for so long viewed as completely beyond question, now stands reformed and re-evaluated, if not rebuilt altogether. Similarly, as Edwards has noted, the decision in HS2 also marks a 'sentinel warning of the ultimate supremacy of the UK courts to say what the British constitution means.' ${ }^{\prime 20}$ Whilst legally therefore, the decision in HS2 significantly reforms our understanding of the scope and ambit of the doctrine of the supremacy of EU law and its relationship with the UK constitutional order, in practice it is also likely lead to a substantially greater level of legal protection for UK constitutional values and a more assertive approach by its judicial organs. On any reading, this is undoubtedly a positive result for all and represents a fitting conclusion for the first trip by the Court on an otherwise highly divisive Government infrastructure project.

\footnotetext{
${ }^{118}$ Hale (n 111) 205.

${ }^{119}$ Ibid.

${ }^{120}$ D Edwards, 'HS2: The First Spike’ (2014) 26 Journal of Environmental Law 319, 329.
} 